Paper received: August $6^{\text {th }} 2015$

Paper accepted: October $20^{\text {th }} 2015$

Muller Mirza, Nathalie ${ }^{1}, \mathrm{PhD}$

University of Lausanne, Institute of Psychology,

Original Paper

Faculty of Social Sciences, Geopolis - UniL Mouline, Switzerland

DOI:10.5937/inovacije1503145M

\title{
Can we Learn through Disagreements? \\ A Sociocultural Perspective on \\ Argumentative Interactions in a Pedagogical Setting in Higher Education
}

\begin{abstract}
It has been well established by educational research that social interactions play a role in learning and development. In this paper, we draw on recent advances in a sociocultural perspective in psychology that have showed the dialogical dimension of learning, and allowed to consider social interactions as a matrix for its development rather than a variable merely "influencing" psychological processes.

In educational contexts, argumentative interaction is often considered as a potential means to learn. However, in some cases, the results of argumentative activities do not reach the learning gains expected by the teachers: the students engage in an irenic confrontation trying "to win", or face difficulties in elaborating counter-arguments and contents which allow an effective epistemic exploration of the topic under discussion. One of the main difficulties for the interlocutors seems "to agree to disagree" and to develop the topic with relevant information. This paper, drawing on a sociocultural perspective on argumentation, has two main objectives: the first is to explain the theoretical outlines of a pedagogical design implemented in a university course in social psychology. This design was conceived in order to lead the students intending to explore a complex question to enter into an epistemic discussion. The second aim is to present and discuss the results of the analysis of the argumentative discussions developed by the students. Did they agree to disagree? How did they manage disagreements? Did their disagreements lead them to an epistemic exploration? The data are made up of 11 chat sessions in which 35 students participated in small groups of 3 or 4 . The analysis focuses firstly on the structure of the sessions and secondly on the argumentative moves. The results show that the students co-construct a social frame in which the disagreements can be expressed and the "deep" exploration of the topic can be developed in a cooperative framework. This finding is discussed by examining the role of the general meaning of such a setting in an academic context.
\end{abstract}

Key words: sociocultural approach, learning, argumentation, disagreement, design.

1 Nathalie.MullerMirza@unil.ch 


\section{Introduction}

In the context of education, research highlighting the central role of social interactions - and in particular argumentation - in development and learning has induced concrete pedagogical practices. For example, in the new curriculum for primary school in the French-speaking part of Switzerland, the wording "debate" appears many times in the text. It is associated with three main meanings: debate is considered as an object of teaching and learning in itself (as in French lessons when the students are familiarized with argumentative skills, for instance), as a means that allows developing new knowledge and a scientific posture (as in mathematics, sciences and social sciences), but also as a means promoting collaboration among students in order to contribute to "respectful social relationships" (http://www. plandetudes.ch/). Social interactions, group discussions and debates have became relatively familiar practices in classrooms. However, today, some criticisms emerge: the actual benefit of group work in terms of learning is more difficult to observe than anticipated and the difficulty of assessing learning gains is tackled. Some researchers in sociology even claim that teaching practices based on debate and group discussions can paradoxically promote social inequalities for the most vulnerable students (Bonnéry, 2015).

Taking a sociocultural perspective on argumentation, some authors shed light on the cultural and communicational dimension of argumentation that cannot be reduced to a system of formal procedures but is situated in a relational and institutional setting (Muller Mirza, Perret-Clermont, Tartas \& Iannaccone, 2008). Argumentation is framed by the activity in which individuals are involved and the way they provide a meaning to this activity. Moreover, from a conversational perspective, the interlocutors in an argumentative discussion seem to face a double difficulty that Traverso (2001) calls a "contradictory pressure": the "pressure of the relationship", that generally in a conversation leads to a preference for agreement and the avoidance of disagreement, and the "pressure of the content", i.e. to remain consistent and develop the topic under discussion.

In this paper, we will present and discuss a pedagogical design which intended to lead the participants to "agree to disagree" and to explore a complex question in an epistemic way. This question was taken from a debate in social psychology related to the experience of Jane Elliott about discrimination (this experience, aiming at letting the students experience discrimination, has been criticized for ethical reasons). The pedagogical design we will examine aimed at developing knowledge about discrimination and its psychosocial processes by means of a "role-play" in which the students played the role of psychologists who were asked to help social workers facing racial violence among their own students. In the first section of the paper we will refer to studies on social interactions adopting a sociocultural and dialogical perspective that claim that social interactions cannot be seen as a simple variables that "influence" learning processes. In the second section, we will develop the idea that argumentation is a cultural activity with its own cognitive but also relational, affective and communicative specificities. In the third section, we will present the theoretical outlines of the pedagogical design implemented in a university course in social psychology. After a presentation of the methodological tools we used to analyze our data, made up of 11 chat sessions in which 35 students participated in small groups of 3 or 4 , we will discuss the results of the analysis of the argumentative discussions developed by the students. Did they agree to disagree? How did they manage the disagreements? Did their disagreements lead them to an epistemic exploration? The analysis focuses firstly on the structure of the sessions and secondly on the argumentative moves. By examining a specific design and explaining its theoretical background, we hope to contribute to the reflection both on the complexity of interactional processes in knowledge construction and on the conditions of its dynamics. 


\section{A Sociocultural and Dialogical Perspective on Interactions and Learning}

In the field of research on social interactions, we could distinguish two main strands of studies: one focusing on social interactions as factors of cognitive change, and another considering social relationships as an integral part of human development, in which language is a central cultural artifact for cognitive and social development (Baucal, Arcidiacono, \& Buđevac, 2011). In this paper, we adopt the second strand, which we shall call a "sociocultural and dialogical" perspective on social interactions, that considers the interaction as the unit of analysis in which learning is elaborated within complex dynamics, entailing the active participation of the individuals in meaning-making processes, and postulating a central role for the heuristic negotiation of disagreements.

Some scholars who studied the role of social interactions for cognitive development, and in particular socio-cognitive conflicts, in the late 70s and in the 80s (Doise, Mugny, \& Perret-Clermont, 1975; Perret-Clermont, 1980), later on shed light on the interpretative processes pertaining to the dynamic of the interaction. Adopting a sociocultural approach, in continuity with authors such as Vygotsky, Mead or Bakhtin, these researchers focused on the dialogical relations of cognitive, relational, affective and institutional dimensions of learning (Grossen, 2009; Muller Mirza \& Perret-Clermont, 2009; Muller Mirza, 2014; Perret-Clermont \& Nicolet, 2001; Pramling \& Säljö, 2014; Schubauer-Leoni, Perret-Clermont, \& Grossen, 1992; Tartas, Baucal, \& Perret-Clermont, 2010). In this perspective, social interaction is seen not only as part of human life but also as the engine which drives an individual's psychological development (Psaltis, Gillepsie, \& PerretClermont, 2015). Their research then showed that the relational dimension is not an external variable but the locus in which the interlocutors are engaged in meaning-making processes. The participants refer to symbolic and material elements pertaining to the micro-context of the situation and also to past experiences and future situations in which they imagine being involved (Bruner, 1990; Grossen, 2009). For the purpose of this paper, let us focus on some main ideas drawn from this theoretical perspective.

If interactions are at the core of psychological development, a "factorial" definition of their role is not sufficient to understand the dynamics of thinking. In contrast, a dialogical definition of interaction leads to focusing no longer on the individual, but on the relationship between ego and alter (conceived as individuals but also as different facets of the self) (Grossen, 2014; Marková, 2007; Wertsch, 1991). Some studies show for example that the responses of a child in a test situation are the results of processes of communication between an adult and a child in which both are engaged in an interpretative work aiming at defining the meaning(s) of the situation and the task (Grossen, 2009). The object of inquiry for researchers is not (only) the product of the interaction but the dialogical processes developing during the interaction, with a particular interest in the perspective of the actors and the way they confer meanings on the situation.

Another lesson provided by some of these studies is the idea that tensions, hiatus and conflicts are part of any interaction. Social interactions entail agreements and disagreements (Matusov, 1996), and disagreement is neither nuisance nor obstacle, but on the contrary an essential ingredient of the dialogue. Studies in the field of the socio-cognitive conflict in social psychology of development showed that the confrontation of perspectives, and especially its resolution on a higher plane, can lead children to look for new information, explanation and coordination of the points of view even before the formal operation stage, under certain conditions (PerretClermont, 1980). However, the positive effect of a socio-cognitive conflict on development seems conditioned by the mode of regulation of the conflict: the "epistemic conflict regulation" mode, focusing on the correctness or validity of knowledge, seems 
more beneficial than a "relational conflict regulation" mode, centered on the relative statuses of the partners (Butera, Darnon, \& Mugny, 2011). Opening the scope of a factorial analysis of socio-cognitive conflicts, some researchers pointed out the fact that the situation of socio-cognitive conflict is itself a social situation in which contextual, institutional and identity dimensions are embedded (Baucal, Arcidiacono, \& Budjevac, 2013; Grossen, 2009; Muller Mirza, Baucal, Perret-Clermont, \& Marro, 2003; Psaltis \& Duveen, 2007; Tartas et al., 2010). The way the subjects carry out the task and give responses to their interlocutors is the result of psychosocial processes. This research leads today to studies that focus on the dialogical relationships or tensions that arise between different voices: those pertaining to the here-and-now of discourse as well as those pertaining to the there-and-then of discourse which echoes the voices of absent third parties (Grossen \& Salazar Orvig, 2011; Zittoun \& Grossen, 2013).

In this perspective, language plays an important role. It is the means for providing information to the other but also and mainly, in Vygotskian words, where intermental processes are transformed into intramental processes (Littleton \& Mercer, 2013; Mercer, 2000; Vygotsky, 1988). Language however is not the only semiotic psychological tool. Objects and, in the context of school, books, manuals, black and white boards, software, etc., are parts of the symbolic and material systems of mediation that play an important role in teaching and learning (Cole, 1999; Moro \& Muller Mirza, 2014; Sørensen, 2009).

These considerations lead educational scholars to suggest that argumentation, as a social, cognitive and dialogical activity, which develops in social interaction characterized by a disagreement, when there is a "discursive confrontation during which antagonistic responses are provided to a 'question"' (Plantin, 1996a, p. 11, my translation), might facilitate learning, thinking or, more broadly, the exploration of an object of knowledge. Researchers have showed that argumentation in educational contexts can lead to the construction of new knowledge, foster the elaboration of agency by the learner and help students to enter into a scientific culture (Baker, 2004; Muller Mirza \& Buty, 2015).

\section{Argumentation as a Cultural Activity}

Pedagogical activities that aim at teaching and learning topics by means of debate and argumentation might lead, however, to interactional dynamics that were not anticipated by the teachers: in some cases, the students may engage in an irenic confrontation trying "to win" at all cost; in other cases they face difficulties in elaborating counter-arguments and contents to allow an effective epistemic exploration of the topic under discussion. Here again a factorial or linear perspective on argumentation in learning is not sufficient.

Many hypotheses have been developed in order to understand the challenges of argumentation in learning (Andriessen \& Schwarz, 2009). Argumentation involves various epistemic and relational abilities: taking a stance towards a content (which is situated in a broader debate), providing reasons (referring not only to the personal goal but also to shared knowledge), using linguistic tools, managing arguments pro and contra, etc. Conversationalists and developmental psychologists suggest other possibilities as well. They help us understand that argumentation is a cultural practice that is situated in specific contexts and governed by implicit rules, and a cognitive activity that a child develops. Voss and Van Dyke (2001) observe that young children have personal experience in conflict situations very early in life. Even though they are unable to verbalize the nature of argument structures, they engage actively in argumentative discussions, using justification and negotiation strategies. However, the knowledge and the experience they have of a specific topic will differ and this knowledge can explain some difficulties faced by young children in responding 
to researchers who, in trying to evaluate their "argumentative skills", ask them to develop arguments and counter-arguments about complex topics such as capital punishment or why people should return to prison: "Whether or not a person is able to perform reasonably in an argumentative situation depends on context, which includes the argument's contents" (Voss \& Van Dyke, 2001, p. 103). Other scholars who study conversation in everyday contexts stress the contextual and identity dimensions of argumentation. Along this line Pontecorvo, Arcidiacono and their colleagues analyze argumentation in family contexts and during family dinners in particular. They show how the context of production, as a secure and familiar setting for exploration, plays an important role in socialization of children (Arcidiacono, 2009). By arguing with significant others, in personally meaningful situations, children learn not only how to argue, how to use language to communicate and think, but also social rules (how to behave, how to ask and respond to whom, what are the accepted codes, etc.), and finally what it means to be and become members of a group (Pontecorvo, Fasulo, \& Sterponi, 2001; Stein \& Albro, 2001). If argumentative sequences can be observed in family contexts or in other conversational genres such as political debates, it seems however that situations in which the participants discuss critically (van Eemeren \& Grootendorst, 2004), develop a "question" (Plantin, 1996b), elaborate the disagreement, explore different positions in a heuristic way, are relatively rare. This operation indeed, in everyday conversation, is submitted to what Traverso (1999), a sociolinguist, calls a "contradictory pressure" between, on the one hand, the "pressure of the relationship" and, on the other, the "pressure of the content". Let us develop this idea further.

Conversational analysts have shown that one of the best attested patterns is the preference for agreement in the second turn of an adjacency pair. It means that when a person makes an assertion or performs another conversational action, a response that is to be taken as agreeing will typically be im- mediate, while a response to be taken as disagreeing will be prefaced or delayed (Myers, 2004; Sacks, 1987). Pomerantz (1984) sheds light on the tendency to systematically minimize the disagreement by means of modalisators or of a particular organization of the turns to speak characterized by hesitation, pauses or partial agreement. This is related to the notion of figuration or face management developed by Goffman (1974) and others (Brown \& Levinson, 1987). When a divergence is expressed, interlocutors try to preserve their face by minimalizing the threat.

However, participants in a dialogue not only engage in this "face work" but also have to deal with another pressure: that of being "consistent", i.e. to develop and contribute to the content of the discussion. These two pressures function as a double constraint for the participants who have to both show their consistency and manage the face work.

Argumentation is therefore "embodied" in actual communicative practices, oriented towards certain goals, towards other participants (be they present or physically absent in the situation), and towards specific topics. Argumentation cannot therefore be reduced to a system of formal procedures (Nonnon, 2015; Santos \& Leitão Santos, 1999). It is framed by the activity in which individuals are involved, the rules of the conversation, their role expectations, and their definition(s) of the situation. Conceiving argumentation in this perspective means a methodological shift of focus: the unit of analysis is no longer the structure of the discourse, nor the individuals (their competences and skills, their cognitive level of development, etc.), but the "activity" of argumentation involving meaningmaking processes.

\section{Argumentation to Learn: the Ingredients for "Argumentative Designs"}

The "argumentative" practices used in classrooms aiming at learning a specific topic (for instance 
in mathematics) are often oriented towards argumentative skills (giving reasons, supporting evidence, etc.) in situations in which all the participants are already convinced or expect to be convinced, and conform to what is expected of them following a classical didactical contract (Schwarz \& Baker, 2015). However, argumentative activities rarely lead to a "co-construction of meaning". In order to overcome this difficulty, some scholars have made heuristic suggestions. Let us here examine the studies of Neil Mercer and his colleagues in particular.

Drawing from the Vygotskian statement of the interdependency of social interaction, language and development, they observe that in teaching and learning settings, the most productive discursive patterns are those in which the disagreement is not only made explicit but also explored in a joint activity (Littleton \& Mercer, 2012, 2013; Mercer \& Wegerif, 1999; Rojas-Drummond, 2009). This type of discourse is called "exploratory talk" and is defined in the following terms: "Exploratory talk is that in which partners engage critically but constructively with each other's ideas. Statements and suggestions are offered for joint consideration. These may be challenged and counter-challenged, but challenges are justified and alternative hypotheses are offered. Partners all actively participate and opinions are sought and considered before decisions are jointly made" (Mercer, 2004, p. 146). It means that exploratory talks are characterized by the fact that agreement is postponed, disagreements are expressed and justified, the validity of the statement is an object of discussion, any disagreement is introduced in a cooperative frame and therefore submitted to a negotiation procedure (Mercer, 2000). These authors also insist on the fact that this type of talk should be the result of teaching and reflexive activity on the functioning of communication with students. Teachers therefore play an important role by presenting, explaining and discussing the conversational rules the "ground rules" - that will support exploratory talk. In this perspective, the heuristic and collaborative exploration of the disagreement appears central.

\section{Studying Argumentative Design in Practice}

These theoretical notions can be used as a basis for the design of argumentative settings. This is the idea that I would like to develop now by discussing a concrete example (Muller Mirza, 2015). At the University of Lausanne I give a lecture in sociocultural psychology on thinking and learning with Master students in psychology. The lecture is taught during a semester (14 lessons of 1 hour and a half a week). Two main topics are developed: the first on dialogue and argumentation in diverse everyday contexts, and in particular in school, and the second on intergroup relationships with a focus on social categorization and discrimination. In order to get an opportunity to practice argumentation in learning and to explore a complex topic, the students are invited to attend different activities as part of the course validation process. The main goal is to tackle the topic of social discrimination and its psychosocial processes by means of a "role-play" in which the students play the role of psychologists who are asked to help social workers facing racial violence among their own students. The social workers are deemed to be interested in getting information about discrimination and racism from the scientific literature in social psychology, and some advice about activities which could help them to reduce the violence among their students. They also ask the "experts" whether Jane Elliott's experiment could be useful for this purpose. This experiment, well known in social psychology, is called "blue eyes-brown eyes", and was designed by a teacher, Jane Elliott: one morning, the class of third graders are told by their teacher that blue-eyed people are smarter and better than brown-eyed people, and the next day, she reverses the exercise, promoting brown eyes as better than blue eyes ${ }^{2}$. Jane Elliott conceived this exercise and tested it with her pupils just the day after Martin Luther King Jr was assassinated in 1968. This exercise

2 Frontline "A Class Divided" (1985)

$<$ http ://www.pbs.org/wgbh/pages/frontline/video/flv/generic. $\mathrm{html} ? \mathrm{~s}=$ frol02s $42 \mathrm{cq} 66 \&$ continuous $=1>$. 
has been at the core of a debate in literature: Jane Elliott and others were convinced by the power of the emotional experience of taking alternatively the role of the discriminator and the discriminated in order to reduce the risk of discrimination in society; other researchers, on the contrary, mainly on ethical grounds, expressed their reluctance to make children feel such strong emotions.

In this perspective, the master students are invited to participate in three main tasks:

1) To prepare for a meeting in which they are supposed to speak as "experts" of psychosocial processes in intergroup relationships. The students in small groups of 3-4 participants have to read papers and books about categorization and discrimination in social psychology, and to organize the discussion;

2) To discuss argumentatively about Jane Elliott's experiment. In order to sustain the discussion among the students, the role-play is organized around discursive roles: one participant has to take the role of "pro" and another the role of "contra" the idea of using Jane Elliott's exercise in this context. A third participant takes the role of the discussion moderator. This discussion is mediated by a chat program that allows to record the interaction in writing and therefore to come back to it if necessary;

3) To draw up a collective report at the end of the discussion, in which they describe the psychosocial processes at stake in intergroup communication and "respond" to the social workers about the contributions and limits of Jane Elliott's experience. They conclude, individually, with a general reflection about what they learned from this exercise, from their student's perspective.

The design of this exercise integrated some elements learned from the theory about argumentation in educational settings: in order to facilitate the heuristic elaboration of disagreement and sustain the development of exploratory talk, the role-play was meant to lead students to express and examine different perspectives about the "question"; the conceptual preparation with the help of scientific litera- ture was meant to provide them with contents they could refer to during the argumentative setting in order to develop and elaborate the question more deeply; the chat was meant to mediate the discussion in order to allow them the reflexive stance provided by writing, and facilitate the face work.

\section{Method}

\section{Participants}

The corpus is made up of 11 chat sessions written by the 35 students attending the course. Each session (that lasted 90 minutes on average) was mediated by a chat tool integrated into a Moodle platform. During the sessions, each participant worked with his or her computer. They had to log in and their name appeared on a window shared by all the students: everybody could then write and see the text of the others in a synchronous way. Each intervention - a "turn-taking" -was automatically associated with the name of the interlocutor and the time. The 11 texts total 29,927 words; i.e. an average of 2,720 words and 90 turn-takings per group.

Let us recall that each group was made up of three or four participants: one played the role of a "Proponent" (in favor of Jane Elliott's exercise), another of an "Opponent" (contra Elliot's exercise) and a third of a Mediator (the moderator of the chat discussion). In some groups, a fourth student took the role of a second moderator or of a social worker who participated in the discussion. The instruction for each group was the following: They had to organize a work session among them as "psychologists" in order to both reflect on and mobilize knowledge about a complex topic, and to respond to social workers facing problems of racial violence.

\section{Data Analysis}

The analysis of these data has been carried out in two main steps: 
1) In order to have a better view of the structure of each session, each of these has been divided into discursive sequences. Chat discussions were observed as structured around three main sequences: an "opening phase", a "phase of development", and a "concluding phase". This step aimed at identifying how the students organized their discussion but also at examining how the "question" was thematized;

2) The second step aimed at examining one of the main elements of an exploratory talk which interested us particularly, i.e. whether and how disagreements were expressed and how they were negotiated in the interactional moves. In this perspective, the analysis has been done by means of a schema elaborated on the basis of the suggestions made by Traverso (1999) and Leitão (2001), aiming at analyzing the "negotiation of the disagreement" in argumentation (see also Muller Mirza, Tartas, et al. 2007). The schema is made of three main elements:

- A1 (argument 1): A proposition and its justification, made by the Proponent (for ex.: "Speaking for myself, I believe that shedding light on the factors of discrimination will allow to develop tolerance and open-mindedness" ${ }^{3 \prime}$ [Pour ma part je suis d'avis que la mise en évidence des facteurs qui sont à l'origine de la discrimination va permettre de développer la tolérance et I'ouverture aux autres].

- CA1 (counter-argument 1): Disagreement on A1 or on one element of A1 (for ex.

"The method used by J. Elliott

(...) would be considered as a very violent and radical one

3 The extracts are translated from French to English. The original text in French appears in square brackets without any orthographical modification. The names of the students are pseudonyms. Before the activity, the students were told that it was part of the validation of the course and that the teacher would read their text. After validation, they were asked if they agreed that their texts could be used in the framework of a research project. by the authors of the website Mrax.be" [ La méthode employée par J. Elliott serait (...) jugée très violente et radicale comme le rapportent les auteurs du site web Mrax.be]).

- R (response): Agreement on A1, on CA1, disagreement on A1, on CA1, or alternative (for ex.: "to work on prejudice and/or stereotypes actually seems a very relevant idea to me. However, they must be handled carefully"

[Travailler sur les préjugés et/ou les stéréotypes me semble effectivement être une idée pertinente. Cependant, il faut les traiter avec prudence").

For this analysis, it was important to take the content of the discussion into account. I then examined the "dimensions of the debate" to which the participants referred when justifying or attacking the argument of the other. The main dimensions identified are the following:

1) The scientific validity of Jane Elliott's exercise

2) The ethical dimension of the exercise

3) The emotional pressure felt by the participants

4) The characteristics of the population at stake

5) The feasibility of the exercise

6) The issue of intimate experiencing of racism and discrimination.

\section{Results and Interpretation}

\section{The structure of the sessions}

Analysis shows that all 11 chat discussions are organized around three discursive sequences of various lengths: an opening phase, a phase of development and a phase of conclusion. 


\section{Opening phase}

The analysis of the opening phase shows that it includes different discursive actions through which the participants negotiate and co-construct three main issues together: 1 ) a relational issue (the participants recall and state the reasons underlying their work and the role each of them should play); 2) the general context of the "question" they have to discuss; 3 ) the terms of the "question" itself. Let us discuss some examples extracted from the chat discussions.

\section{1) The relational issue}

Here are two examples. Mary and Melanie, who play the role of moderators in their respective group, open the meeting.

\section{Extract 1}

Mary Hello, thank you for being here. Before starting the discussion, I would like to recall our objective and the request which has brought us together today

Bonjour, je vous remercie d'être présentes ici. Avant de commencer notre discussion, je souhaiterai faire un petit récapitulatif de notre objectif et de la demande qui nous réunis ici

\section{Extract 2}

Mel We received a request to help them with this situation. The social workers also wish to get an account of the state of the art on this topic. This is what we are meeting to discuss.

Une demande nous a été adressée de leur part, afin de leur venir en aide dans cette situation. Les éducateurs du foyer désirent également avoir un compte-rendu de l'état des connaissances disponibles à ce sujet. Ainsi, nous nous sommes réunies fin d'en discuter (DAA3).
What do Mary and Mel "do" in these extracts? They settle what is expected from their meeting: to help the social workers to solve a problem, to provide them with an account of the scientific knowledge on the topic. In making this reminder they define the purpose and role underlying their meeting. They also define their own discursive identity and attribute specific roles and functions to the others.

2) The context of the "question"

In this opening phase, the participants, sometimes in a joint activity, provide information about the context of the problem they have to discuss, as one can see in the following example.

\section{Extract 3}

1. Ann The demand originates from a shelter for teenagers from 15-17 yo with host family difficulties

La demande émane d'un foyer accueil pour adolescents entre 15-17 ans avec des difficultés familiales d'acceuil

2. Rose The persons, all male, spend the whole week in the shelter and come back home at the week-end Les individu, tous masculins, passent leur semaine au foyer et rentrent chez eux les week-ends

They eat all together and share collective activities

Ils mangent ensemble et ont des activités communes

On several occasions the social workers have observed a psychological and physical bullying between two groups of young people, made up respectively of people from North Africa, and of a majority of Caucasian people.

A plusieurs reprises, les éducateurs ont constaté un harcélemet psychique et physique entre deux groupes de jeunes, constitués 
$d^{\prime}$ une part de personnes d'origine maghrébine pour les uns et majoritarement d'individus caucasiens pour le second groupe

In this extract 3, Ann (who plays the role of the Opponent) but mainly Rose, the Mediator of the discussion, together explain the context of the request: where does the request come from and what is the specific problem faced by the social workers.

3) The formulation of the problem itself

The participants accomplish another discursive task in this opening phase: to provide further information related to the problem they, as experts, will have to discuss. In the next example, Estella puts the "question" into words and uses the formulation "whether... or" typical of the introduction of a controversial topic.

\section{Extract 4}

Estella

\begin{abstract}
The social workers were interested in the study conducted by Jane Elliott and in other designs as well. They would like to know whether or not it is possible and relevant to perform an experiment in the framework of their institution, or to receive suggestions about other methods to be implemented

Les éducateurs s'étant intéressés à l'étude menée par Jane Elliott ainsi qu'à d'autres dispositifs, souhaiteraient savoir s'il possible voire pertinent de mener une expérience au sein de leur institution ou recevoir des propositions de méthodes à mettre place
\end{abstract}

These examples show that the participants spend some time before entering into the discussion itself in order to "frame" the situation. They seem to construct and provide elements allowing them to respond to the question of "What is it that's going on there?" that people ask generally when engaging in a new situation (Goffman, 1974). They select specific elements that will contribute to how they interpret the task to be performed. This process of framing, as we can see here, is the result of the participants' collective activity. Interestingly, what is explained and defined relates not only to the content of the "problem" (bullying and discrimination between groups of young people in a shelter) but also to the nature of their own relationships in the role-play. By the numerous uses of the pronoun "we", contrasted with the "they" associated with the social workers, and by formulations such as "this is why we are all here today", the relationship is settled and defined around the idea of collaboration.

\section{Phase of development}

The second phase is the longer. It is made up of numerous arguments, counter-arguments, refutations, explanations, examples, quotations from texts, etc. which develop the "question" about the legitimacy of Jane Elliott's exercise as a possible solution to the problem of the social workers. In the section "Argumentative moves", we shall come back to the analysis of the dynamics evolving in this phase.

\section{Concluding phase}

From session to session, the concluding phase can be very short (one turn-taking) or longer. Generally we can observe the same two dimensions that were thematized in the opening phase: a focus on the content (the participants, in general the Moderator, synthesized the main points of the discussion) and a focus on the relationship (the participants thank each other and say goodbye).

Here is an example illustrating the way one participant takes time to recall systematically ("firstly", "secondly"...) and argumentatively ("it has its benefits but...") the main ideas developed by the group during the session. 


\section{Extract 5}

Marilyn

\begin{abstract}
Unfortunately, it is time to conclude the meeting. I would like to draw up a summary of the main points we tackled in order to transmit them to the social workers. Firstly, the fact that J. Elliott's experience does not seem without risk. This design has its benefits (...) but it does not seem adapted to the context of the shelter and could provoke more differentiation and violence (...). Secondly the design suggested by Aronson...
\end{abstract}

Malheureusement il est temps d'achever la séance. J'aimerai donc résumer les éléments importants que nous avons abordés afin de pouvoir les transmettre aux éducateurs. Premièrement le fait que l'expérience de J. Elliott ne semble pas sans risque. Ce dispositif à des avantages (vécu de la discrimination, diminution des stéréotypes) mais elle ne semble pas adaptée au contexte du foyer et pourrait créer plus de différence et de violence (....). Deuxièmement le dispositif proposé par Aronson...

Extract 6 shows a typical example of an explicit focus on the relationship. The words used by the three participants in an articulated way indicate a definition in positive terms of the way they worked together (rich discussion; valuable cooperation: repetition of mutual thanks, with pleasure...).

\section{Extract 6}

1. Jess: Yes, indeed, we'll talk about this point during our next meeting. As we are coming to the end of this rich discussion for today, I thank you for your valuable cooperation

Tout à fait, nous en parlerons lors d'une prochaine séance. Pour aujourd'hui, nous arrivons au terme de cette riche discussion et je vous remercie pour votre précieuse collaboration

2. Emy: Thank you merci à vous!

3. John: It was a pleasure Ce fut un plaisir

4. Paula: With pleasure, see you c'était avec plaisir, à bientôt

This closing phase appears then as a sequence in which the participants synthesize what has been said during the discussion (suggestion of scenarios for example) but also, in term of faces, as a sequence in which the participants "repair" a possible threat to the relationship due to an argumentative phase entailing agreements and disagreements.

This first analysis of the structure of the sessions sheds light on the way the sequence of elaboration of the "question" - the phase of development - is actually framed by the participants: it is jointly prepared in the introduction on the double dimension of the content and the relationship. The opening phase aims at defining the situation in terms of the content that will be the subject of the discussion, but also in terms of how to reach the objective together: the focus in general is put on an idea of collaboration rather than of confrontation. The session is also concluded on these two dimensions by focus- 
ing on a synthesis of the content of the discussion and compensation of the possible negative effects of the argumentative phase.

The phase of development will probably make visible the intricacy of this double dimension. Let us analyze the argumentative moves in this: How are disagreements - if any - made explicit and negotiated? Do we observe some features of what Neil Mercer and his colleagues call an exploratory talk?

\section{Argumentative moves}

The chat sessions of the student groups show a relatively vivid discussion on the topic of Jane Elliot's exercise and its legitimacy. This discussion is characterized by arguments in favor and counter-arguments formulated by the Proponents and the Opponents, referring to the different main dimensions of the debate in terms of contents: the scientific validity of Jane Elliott's exercise, its ethical dimension, the emotional pressure it means for the children, the characteristics of the population at stake (age, gender, etc.), the feasibility of the exercise (time available, skills of the teachers, etc.) and the importance of experiencing racism and discrimination in order to avoid their negative impact. This general observation firstly means that the participants did not use the conversational pattern of preference for agreement in the second turn. Rather they expressed their disagreements. These disagreements were not only expressed but justified, the students offering reasons of their own to back up statements or proposals, through exchanges chained into coherent lines of enquiry rather than left stranded and disconnected (Mercer, 2004).

At this point, three observations can be made.

Firstly, the "chains of lines of enquiry" are made up of several encapsulated sets of ArgumentCounter-Argument and Response (A-CA-R): one pattern of A-CA-R generally opens a new pattern of A-CA-R.
Let us discuss an example. During a chat session, Viviana (the Proponent) claims that Elliott's exercise could be a relevant method to be used by the social workers as it has been tested by researchers. She refers to Stewart, Laduke, Bracht, Sweet and Gamarel's study (2003) that showed that the distress of the children was balanced by the fact that the participants were pleased with the experiment and by changes in attitude towards cultural diversity. Sebastian (the Opponent) counter-argues to Viviana by saying that Elliott's exercise is too emotionally loaded, and suggests the use of other activities. Viviana continues and concedes that the students are under pressure, but states (it is precisely the argumentative strategy she uses in her statement) that Stewart's results show that Elliott's exercise is efficient.

\section{Extract 7}

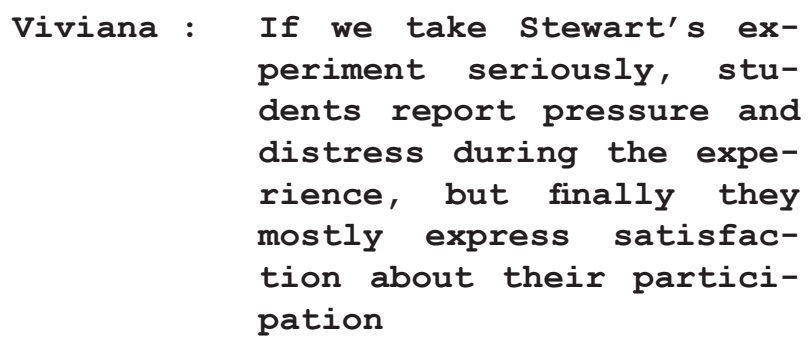

$$
\begin{aligned}
& \text { Si on s'appuie sur } \\
& \text { l'expérience de stew- } \\
& \text { art, les étudiants rap- } \\
& \text { portent une grande pres- } \\
& \text { sion et de la détresse du- } \\
& \text { rant l'expérience, mais au } \\
& \text { final, la plupart sont con- } \\
& \text { tents d'avoir participé]. }
\end{aligned}
$$

Viviana therefore opposes a counter-argument to Sebastian's counter-argument: the fact that not only the students themselves "express satisfaction", but also that Elliott's experiment has been scientifically tested (unlike the activities suggested by Sebastian).

An interesting discussion on the notion of "validity" then develops between Sebastian and Viviana. 


\section{Extract $8^{4}$}

1 Viviana:

2 Sebastian: Yes of course. However, these authors do not come out of the blue and have "tested" their own activities if not objectively, at least live. They interpreted positive responses from the teenagers. Validity does not guarantee everything in the human sciences

3 Viviana: I am not sure I understand how validity does not guarantee everything in the human sciences?

4 Sebastian: Numbers can be made to say anything. I do not mean to put into question Stewart's experiment, but one cannot legitimize everything through science! We are talking about teenagers and human beings; I think that it is clearly more important to take their feelings into account and to place emphasis on positive experiences. With this "pedagogical kit", various activities are related to prejudice and stereotypes. Once again, I think that it is a safe alternative, even though it is not scientifically proven.

4 The original text in French can be found in Appendix 1
5 Viviana: Coming back to validity, I perfectly agree that numbers are not the only way to get to the truth. However, I remain convinced that the fact that Elliott's experiment and its longterm effects have been experimentally validated seem to indicate its efficiency.

6 Paolo: Thank you for these arguments. In my understanding, it does seem to me that you do not agree on a crucial point. In Elliott's experiment, insight is gained by experiencing discrimination in one's own flesh... 1

In the first turn-taking of this extract, Viviana claims (A) that Elliott's experiment is relevant, as it has been tested scientifically. She refers to Stewart's paper that she quoted earlier. Defending the cons position, Sebastian's rebuttal (CA) focuses on the notion of "scientific validity" suggested in Viviana's argument. In this perspective, in turn-takings 2 and 4, he makes two points: firstly, he claims that researchers are engaged in an interpretative activity ("they interpreted...") and that they could miss some important information ("they interpreted positive responses...") - meaning that they have could miss "negative responses". He grounds his claim by saying that the researchers in their study were analyzing the design they had themselves set up ("these authors do not come out of the blue... and have tested their own activities"). This point can then question the "scientific" validity of the work quoted by Viviana in order to ground her position. Secondly he suggests that the meaning of "validity" itself cannot be limited to a single frame, that of science in general, but should be related to the context of its 
production: in this case, as he said, "human sciences". In so doing, he seems implicitly to oppose two worlds. On one side a world of "human beings" and "feelings", and on the other, a world of numbers - the world of science. Sebastian insists on the fact that in their specific situation, "it is more important to take feelings into account" [implying "than numbers"], therefore eliminating the argument of scientific validity used by Viviana. However, Viviana, in 5 , concedes on a point (there is no universal validity of numbers), but it does not mean that the Stewart's study does not show a crucial point in Viviana's eyes: the long-term efficiency of the experiment. With Paolo's utterance (in 5), another chain of discussion opens on the issue of the subjective experience.

The second observation is that these chains of A-CA-R are often made possible by the help of the participant who acts as the moderator. The moderator takes several discursive actions that permit to elaborate the question more deeply and go beyond the initial disagreement, which could otherwise mean the end of the discussion. The moderator synthesizes the arguments made earlier and points one element of disagreement in particular. He also, as in the next extract, re-opens the debate when a first agreement appears between the Proponent and the Opponent.

\section{Extract 7}

\section{Paolo It seems then that you both agree on the relevance of this experi- ment. But does it not, in a par- adoxical way, have negative ef- fects on the children?}

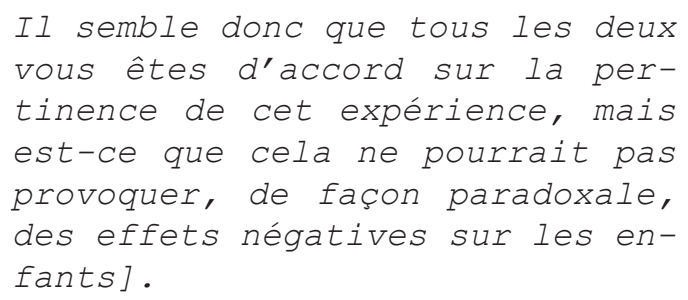

He or she can ask a question of clarification.

\section{Extract 8}

Nic OK... "skeptical"... but how does the difference in age matter?

D'accord..."sceptique"...mais quelle différence l'âge peut-elle faire?

\section{Extract 9}

Jane Your discourse is clear but how do you intend implementing this in practice?

Tes propos sont clairs, mais comment penses-tu mettre cela en place concrètement?

Interestingly, in taking such actions s/he allows avoiding an "agreement on the disagreement" which could also mean the end of the question's exploration.

However, we can also observe that the participants, Opponents and Proponents, sometimes play the role generally devoted to the Mediator, by articulating, verifying their understanding with questions such as "Do we agree?", expressing explicitly when they agree or disagree ("I agree with you, but on that point...", or "I understand your point...", or "you said that but other experiences show that..."). They therefore make the disagreement explicit in a way that does not disqualify the interlocutors but highlights the importance of "thinking together".

It happened several times that an agreement on a disagreement opened the door for the elaboration of an alternative, like in a sequence (extract 12) in which the Opponent and the Proponent agree on the fact that Jane Elliott's exercise is not feasible in the context of a shelter, for ethical and organizational reasons, and together explore the idea of using Elliott's video and other exercises.

\section{Extract 10}

1. Jenny Yes, you are right. Especially as the personality of the teacher plays a central role. I think that not anyone could play this 
role and have such an impact. Let us look then for another design to be set up...

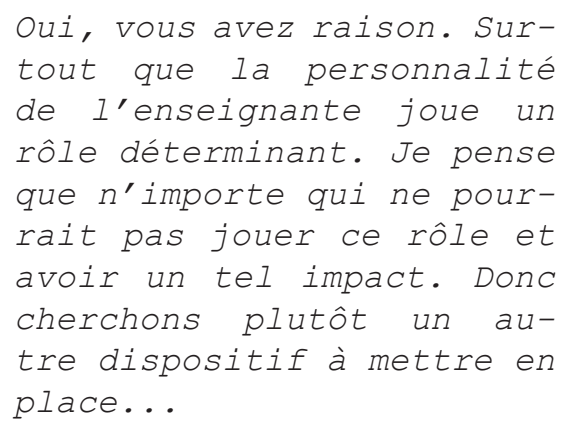

2. $\mathrm{Kim}$

OK. I have an idea! We could suggest an outreach session by watching the video of Jane Elliott's experiment. In doing so, it would allow a first awareness...

OK. J'ai une idée! Nous pourrions proposer une séance de sensibilisation en visionnant la vidéo de I'expérience de Jane Elliott. De ce fait, cela permettrait une première prise de conscience...

3. Jenny Yes, but it would also be a good idea to suggest other outreach workshops in order to keep this awareness vivid

Oui, mais à ce moment là il serait bien aussi de proposer d'autres ateliers de sensibilisation pour maintenir cette prise de conscience

The third observation is related to the role of concession. In all the 11 chat sessions written by the students, we can observe an important occurrence of the form "yes, but", generally prefacing the expression of disagreement. The word "but" appears in the fourth position of the most used words (of 3 letters and more) in the 11 texts. A deeper analysis of 5 chat sessions (377 turns of speaking and 15'995 words) shows that "but" and "however" (in French: mais, néanmoins, toutefois) appear together 83 times (that represents $0.51 \%$ of the weighted percentage, calculated with Nvivo10) when introducing a counter-suggestion or a concession. In general, the "yes, but" is used by the Opponent (37\%) but also the Proponent (33\%) and the Moderator $(20 \%)$ or by other participants (10\%).

The word "but" has numerous functions in discourse. Generally it is meant to avoid a direct confrontation. However, in the chat sessions, other functions can be mentioned such as the introduction of a counter-argumentation or of a doubt that allows the participants to come back to a specific element of the discussion. Sometimes, the concession is integrated in the argument itself (as seen in extract 7), making counter-argumentation more difficult.

If we observe that out of the 11 groups' chat sessions, 7 conclude by not suggesting the use of Jane Elliott's exercise and 4 suggest using Jane Elliott's exercise - or only its video and subject to specific training, a debriefing and/or coordination with other exercises - we can make the hypothesis that the "yes, but" has major argumentative force.

\section{Conclusion}

They are many ways to consider the role of social interactions in development and learning. If we agree to simplify the epistemological and methodological diversity of research in this field, we could distinguish two main strands of studies: one strand focusing on the social interactions as factors of cognitive change, and another considering social relationships as an integral part of human development, in which language is a central cultural artifact for cognitive and social development. In this paper we adopted this "sociocultural and dialogical" per- 
spective on social interactions that considers that the unit of analysis is the interaction as a whole, in which learning is elaborated within complex dynamics entailing the active participation of the individuals in meaning-making processes. In an educational context, a dialogical approach to social interactions entails two main assumptions among others: firstly, the idea that teaching and learning through social interactions can generate unexpected results, like producing irenic behaviors or passivity by the students, and secondly, the idea that disagreements and tensions are not only part of any interaction but can also be ingredients in knowledge construction.

With this (paradoxical) point of departure, in this paper, I presented a pedagogical design in which the participants were invited to discuss a complex topic in social psychology in an argumentative way. The results of the analysis of the discussions, written by master students in psychology during chat sessions, show that the double constraint attested in literature, related to the preference for agreement and the pressure to be consistent, appears less strong than in everyday conversations: the students not only express their disagreements but also explore them in a cooperative framework by submitting them to a negotiation procedure, using argumentative strategies and knowledge contents. The general pattern of the discussions could then be put in parallel with exploratory talks, as defined by Mercer. The other interesting point is that the students seem involved in an important discursive and collaborative work at two levels: at the level of the content (concepts, studies in social psychology and experiments are called upon in order to back up or refute an argument) and at the level of the relationship (strategies of face management - prefacing, repair, modalisators... - definition of the respective roles, verification of a mutual agreement, etc. are important part of the discussion).

These promising findings may be explained (and put into perspective, tempered also) by various features. The sequencialized design that provides time to read and search for information about the topic under discussion before entering the argumentative phase; the format of role-play of the setting that permits a certain distance and freedom to express oneself; the mediation by the chat software that, despite some technical issues, may open space for a reflexive posture. We also have to take into consideration the institutional frame of the experiment: the participants are students (between 25-30 years on average) and not children, quite familiar with academic writing. The fact that the exercise is part of an assessment could also explain the relative richness of the productions. Another point is that this activity could be associated with a professional setting for the participants who are engaged in training in psychology: they had to take on the role of experts in psychology, in a situation which could look close to a professional context of their future position. A student wrote in her personal account, at the end of the exercise:

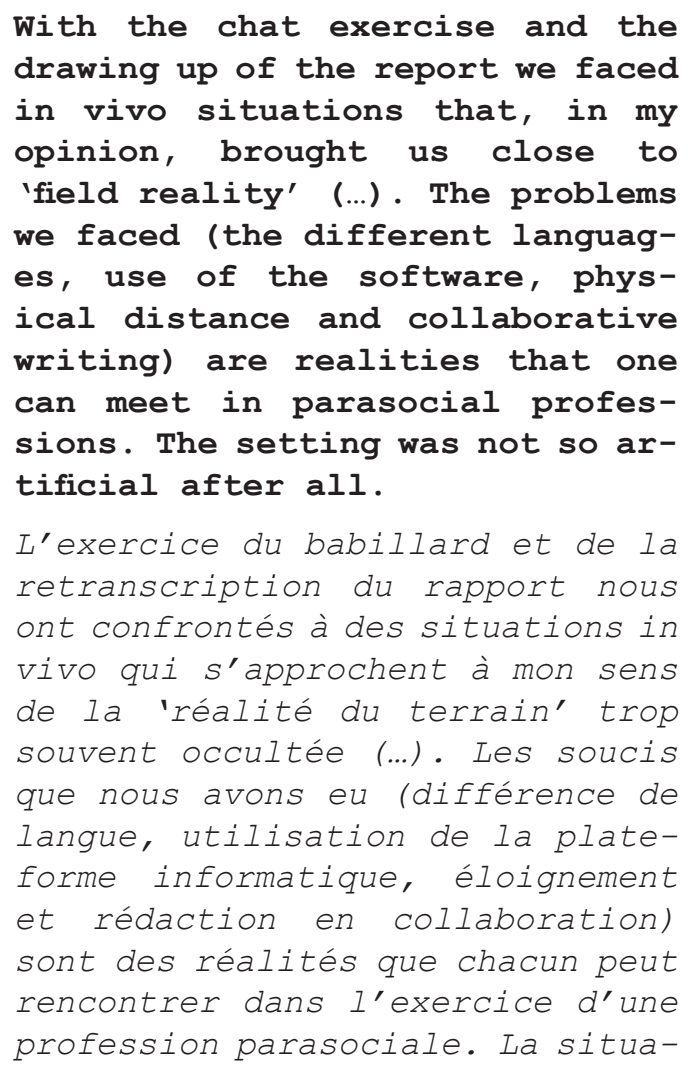


tion artificielle ne l'était en fin de compte pas tant que ça.

Further analyses are needed in order to better understand the complex articulation between social interactions and learning. Of course the reference to (sometimes complacent) discourses of the participants is not enough to evaluate learning benefits of a pedagogical setting. Methodological tools should therefore be developed at different levels and times of the process of learning. It could be interesting for instance to examine if and how the competences mobilized in this training setting are used and useful in the professional contexts in which the students will be involved. Argumentative abilities are an important part of the professional identity of psychologists and scholars in education, although too often neglected in the academic context.

\section{Acknowledgment}

I warmly thank the students who participated in the lecture, and who contributed to the discussion of the results presented in this paper.

\section{Appendix}

\section{Extract 7 (original text in French)}

1 Viviana: (...) L'avantage de l'expérience d'Elliott, c'est qu'elle a été testée et valider par des chercheurs

2 Sebastian: Oui bien-sûr. Néanmoins, ces auteurs ne sortent pas de nulle part et ont "testé", si ce n'est pas objectivement au moins en direct, leurs activités. Ils y ont vu des réponses favorables des adolescents. La validité n'est pas garante de tout en sciences humaines.

3 Viviana: Je ne suis pas sûre de bien comprendre en quoi la validité n'est pas garante de tout en sciences humaine?

4 Sebastian: On fait dire n'importe quoi aux chiffres. Je ne veut pas remettre en doute l'expérience de Stewart, mais on ne peut pas tout légitimer par la science!! On parle d'adolescents et d'êtres humains, je pense qu'il est clairement plus important de prendre en compte leurs ressentis et de se focaliser sur des expériences positives. Par ce kit, plusieurs activités sont relatives aux préjugés et aux stéréotypes. Je pense toujours que c'est une bonne alternative, même si elle n'a pas été prouvée scientifiquement

5 Viviana: Pour rebondir sur la validité, je conçoit parfaitement que les chiffres ne sont pas seuls porteurs de vérité. Néanmoins, je reste persuadée que le fait que l'expérience d'Elliott et ses effets à long terme ont été validés expérimentalement semble néanmoins indiquer que cette expérience est efficace. (...)

6 Paolo: Merci pour ces arguments. En tout cas il me semble de comprendre que vous n'êtes pas d'accord sur un point crucial de l'expérience d'elliott. En effet, dans son expérience, le fait de vivre sur la propre peau l'expérience de discrimination est la source de "I'insight". Il s'agit d'une souffrance et d'une anxiété constructives. Dans cette logique, il semblerait que les activités proposées par Marc s'arrêtent peut-être à un niveau trop superficiel. Est-ce que vous pouvez developper cet argument? 


\section{References}

- Andriessen, J., \& Schwarz, B. (2009). Argumentative design. In N. Muller Mirza \& A.-N. Perret-Clermont (Eds.), Argumentation and education (pp. 145-174). New York: Springer

- Arcidiacono, F. (2009). Cultural practices in Italian family conversations: Verbal conflict between parents and preadolescents. European Journal of Psychology of Education, 24(1), 97-117.

- Baker, M. J. (2004). Recherches sur lélaboration de connaissances dans le dialogue. Nancy: Université Nancy 2.

- Baucal, A., Arcidiacono, F., \& Buđevac, N. (2011). Reflecting on different views of social interaction: Explanatory and analytic perspectives. In A. Baucal, F. Arcidiacono \& N. Buđevac (Eds.), Studying interaction in different contexts: A qualitative view (pp. 233-251). Belgrade: Institute of Psychology.

- Baucal, A., Arcidiacono, F., \& Budjevac, N. (2013). "Is there an equal (amount of) juice?" Exploring the repeated question effect in conservation through conversation. European Journal of Psychology of Education, 28(2), 475-495.

- Bonnéry, S. (Ed.). (2015). Supports pédagogiques et inégalités scolaires. Paris: La dispute.

- Brown, P., \& Levinson, S. C. (1987). Politeness: Some universals in language usage. Cambridge: Cambridge University Press.

- Bruner, J. (1990). Acts of meaning. London: Harvard University Press.

- Butera, F., Darnon, C., \& Mugny, G. (2011). Learning from conflict. In J. Jetten \& M. J. Hornsey (Eds.), Rebels in groups : dissent, deviance, difference and defiance (pp. 31-49). Chichester, etc.: Wiley-Blackwel

- Cole, M. (1999). Cultural psychology: Some general principles and a concrete example. In Y. Engeström, R. Miettinen, \& R.-L. Punamäki (Eds.), Perspectives on activity theory (pp. 87-106). Cambridge: Cambridge University Press

- Doise, W., Mugny, G., \& Perret-Clermont, A.-N. (1975). Social interaction and the development of cognitive operations. European Journal of Social Psychology, 5, 367-383.

- Goffman, E. (1974). Frame analysis : An essay on the organization of experience New York: Harper \& Row.

- Grossen, M. (2009). Social interaction, discourse and learning. Methodological challenges of an emergent transdisciplinary field. In K. Kumpulainen, C. E. Hmelo-Silver, \& M. César (Eds.), Investigating classroom interaction: Methodologies in action (pp. 263-275). Rotterdam: Sense

- Grossen, M. (2014). L'intersubjectivité dans l'étude des processus d’enseignement-apprentissage: Dificultés et ambigüités d'une notion. In C. Moro, N. Muller Mirza, \& P. Roman (Eds.), L'intersubjectivité en questions: Agrégat ou nouveau concept fédérateur pour la psychologie? (pp. 139-160). Lausanne: Antipodes

- Grossen, M., \& Salazar Orvig, A. (2011). Third parties’ voices in a therapeutic interview. Text \& Talk, 31(1), 53-76. doi: DOI 10.1515/TEXT.2011.003

- Leitão, S. (2001). Analyzing Changes in View During Argumentation: A Quest for Method. Forum Qualitative Sozialforschung/ Forum: Qualitative Social Research [On-line Journal], 2(3). Available at: http://www. qualitative-research.net/fqs/fqseng.htm

- Littleton, K., \& Mercer, N. (2012). Educational dialogues. In K. Hall, T. Cremin, B. Comber, \& L. Moll (Eds.), The Wiley Blackwell international handbook of research on children's literacy, learning and culture. Oxford: Wiley Blackwell 
- Littleton, K., \& Mercer, N. (2013). Interthinking: Putting talk to work. London: Routledge.

- Marková, I. (2007). Dialogicité et représentations sociales. Paris: Presses Universitaires de France.

- Matusov, E. (1996). Intersubjectivity without agreement. Mind, Culture and Activity, 3(1), 25-45.

- Mercer, N. (2000). Words and mind. How we use language to think together. London, New York: Routledge.

- Mercer, N., \& Wegerif, R. (1999). Children's talk and the development of reasoning in the classroom. British Educational Research Journal, 25(1), 95-111.

- Moro, C., \& Muller Mirza, N. (2014). Psychologie du développement, sémiotique et culture. Lille : Presses universitaires du Septentrion.

- Muller Mirza, N. (2015). Les paradoxes de l'argumentation en contexte d'éducation: s'accorder sur les désaccords. Analyse d'interactions argumentatives dans un dispositif de formation en psychologie à l'Université. In N. Muller Mirza \& C. Buty (Eds.), Largumentation dans les contextes de léducation (pp. 167-195). Berne: Peter Lang.

- Muller Mirza, N., \& Buty, C. (2015). Largumentation dans les contextes de léducation. Berne: Peter Lang.

- Muller Mirza, N., \& Perret-Clermont, A.-N. (2014). Are you really ready to change? An actor-oriented perspective on a farmers training setting in Madagascar. European Journal of Psychology of Education, 1-15. doi: 10.1007/s10212-014-0238-1

- Muller Mirza, N., \& Perret-Clermont, A.-N. (Eds.). (2009). Argumentation and education: Theoretical foundations and practices. New York: Springer.

- Muller Mirza, N., Baucal, A., Perret-Clermont, A.-N., \& Marro, P. (2003). Nice designed experiment goes to the local community. Cahiers de Psychologie (Université de Neuchâtel), 38, 17-52.

- Myers, G. (2004). Agreeing and disagreeing: Maintaining social argument Matters of opinion: Talking about public issues (pp. 112-133). Cambridge: Cambridge University Press

- Nonnon, E. (2015). Préface. In N. Muller Mirza \& C. Buty (Eds.), Largumentation dans les contextes de l'éducation (pp. 1-11). Berne: Peter Lang

- Perret-Clermont, A.-N. (1980). Social interaction and cognitive development in children. New York: Academic Press.

- Perret-Clermont, A.-N., \& Nicolet, M. (2001). Interagir et connaître. Paris: L'Harmattan.

- Plantin, C. (1996a). L’argumentation. Paris: Seuil.

- Plantin, C. (1996b). Le trilogue argumentatif. Présentation de modèle, analyse de cas. Langue Française, 112, 9-30.

- Pomerantz, A. (1984). Agreeing and disagreeing with assessments: Some features of preferred/dispreferred turn-shapes. In J. M. Atkinson \& J. Heritage (Eds.), Structures of social action. Studies in Conversation Analysis (pp. 79-112). Cambridge: Cambridge University Press

- Pontecorvo, C., Fasulo, A., \& Sterponi, L. (2001). Mutual apprentice : the making of parenthood and childhood in family dinner conversations. Human Development, 44, 340-361.

- Pramling, N., \& Säljö, R. (2014). À propos de la terre et d'autres choses... Des questions, des réponses et l'apprentissage de la catégorisation chez de jeunes enfants en classe de sciences. In C. Moro, N. Muller Mirza, \& P. Roman (Eds.), L'intersubjectivité en questions. Agrégat ou nouveau concept fédérateur pour la psychologie? (pp. 185-210). Lausanne: Antipodes 
- Psaltis, C., \& Duveen, G. (2007). Conservation and conversation types: Forms of recognition and cognitive development. British Journal of Developmental Psychology(25), 79-102.

- Psaltis, C., Gillepsie, A., \& Perret-Clermont, A.-N. (2015). Social Relations in Human and Societal Development. Basingstokes (Hampshire, UK): Palgrave Macmillan.

- Rojas-Drummond, S. (2009). Rethinking the role of peer collaboration in enhancing cognitive growth. Human Development, 52, 240-245. doi: 10.1159/000215073

- Sacks, H. (1987). On the preference for agreement and contiguity in sequences in conversation. In G. Button \& J. R. Lee (Eds.), Talk and social organization (pp. 54-69). Clevedon: Multilingual Matter

- Santos, C. M., \& Leitão Santos, S. (1999). Good argument, content and contextual dimensions. In J. Andriessen \& P. Coirier (Eds.), Foundations of argumentattive text processing (pp. 75-96). Amsterdam: Amsterdam Press

- Schubauer-Leoni, M. L., Perret-Clermont, A. N., \& Grossen, M. (1992). The construction of adult-child intersubjectivity in psychological research and in school. Social representations and the social bases of knowledge. Swiss monographs in psychology, 68-77.

- Sørensen, E. (2009). The materiality of learning: technology and knowledge in educational practice. New York: Cambridge University Press.

- Stein, N. L., \& Albro, E. R. (2001). The origins and nature of arguments: studies in conflict understanding, emotion, and negotiation Discourse Processes, 32, 113-133.

- Stewart, T. L., Laduke, J. R., Bracht, C., Sweet, B. A., \& Gamarel, K. E. (2003). Do the "Eyes" have It? A program evaluation of Jane Elliott's "Blue-Eyes/Brown-Eyes". Diversity training exercise. Journal of Applied Social Psychology, 33(9), 1898- 1921.

- Tartas, V., Baucal, A., \& Perret-Clermont, A.-N. (2010). Can you think with me? The social and cognitive conditions and the fruits of learning. In C. Howe \& K. Littleton (Eds.), Educational Dialogues: Understanding and Promoting Productive Interaction (pp. 64-82): Elsevier Advances in Learning and Instruction Book.

- Traverso, V. (1999). Lanalyse des conversations. Paris: Nathan

- van Eemeren, F. H., \& Grootendorst, R. (2004). A systematic theory of argumentation. The pragma-dialectical approach. Cambridge: Cambridge University Press.

- Voss, J., \& Van Dyke, J. (2001). Argumentation in psychology : Background comments. Discourse Processes, 32(2\&3), 89-111.

- Vygotsky, L. S. (1988). Thought and language. London: Cambridge University Press \& MIT Press.

- Wertsch, J. V. (1991). Voices of the mind: A socio-cultural approach to mediated action. London: Harvester Wheatsheaf.

- Zittoun, T., \& Grossen, M. (2013). Cultural elements as means of constructing the continuity of the self across various spheres of experience. In B. Ligorio \& M. César (Eds.), Interplays between dialogical learning and the dialogical self (pp. 99-125): Information Ag. 


\section{др Натали Милер Мирза}

Универзитет у Лозани, Швајцарска

\section{Можемо ли да учимо кроз неслагање? Социокултурно виђење аргументативних интеракција у педагошком окружењу у високом образовању}

Током истраживања у образовању јасно је уочено да социјална интеракција игра веома битну улогу приликом учења и развоја. У овом раду се бавимо скорашњим напретком социокултурне перспективе у психологији која је показала дијалошку димензију учења и омогућила да се узме у обзир социјална интеракција као матрица за развој, а не психолошки процес који је променљив и који једва има „утицаја“ (Baucal, Arcidiacono \& Buđevac, 2011; Grossen, 2009; Psaltis, Gillepsie, \& Perret-Clermont, 2015).

У образовном контексту, аргументативна интеракција се узима као потенцијално средство учења. Мада у неким случајевима резултати аргументативних активности не постижу циљеве учења које очекују наставници: ученици се конфронтирају и покушавају да „победе“ или да се суоче са тешкоћама приликом развијања контрааргумента и садржаја који допушта ефектно епистемолошко истраживање теме у оквиру дискусије. Једна од главних потешкоћа саговорника је „слагање са неслагањем“ и развијање теме са релевантним информацијама. Узимајући у обзир социокултурну перспективу у вези са аргументацијом, неки аутори су бацили светло на културну и комуникациону димензију аргументације, која не може да се сведе на систем формалних процедура, већ је смештена у релационо и институционално окружење (Muller Mirza, Perret-Clermont, Tartas \& Iannaccone, 2008). Аргументација је уоквирена активностима у које су укључени појединци и начин на који они обезбеђују садржај некој активности. Штавише, из перспективе конверзације, саговорници у аргументативној дискусији се, изгледа, суочавају са дуплим тешкоћама које Траверсо (Traverso, 2001) назива „контрадикторним притиском“: „притиском односа“, аргументација, уопште у разговору, води до слагања и избегавања неслагања и „притиска садржаја“, то јест остаје конзистентна, и развија се тема у току дискусије.

У овом раду представљамо и дискутујемо о педагошком пројекту који је имао за циљ да наводи учеснике да „се слажу или не слажу“ и да истраже комплексна питања на епистемолошки начин, током курса психологије на факултету. Ово питање је узето из дебате из социјалне психологије и односи се на искуство Џејн Елиот у вези са дискриминацијом (ово искуство, које је омогућило студентима да искусе дискриминацију, критиковано је из етичких разлога). Циљ педагошког пројекта био је развијање знања и свести о дискриминацији и њеном психосоцијалном процесу уз помоћ средства „игра по улогама“, у којој су студенти играли улоге психолога, који су замољени да помажу социјалним радницима суоченим са расним насиљем међу студентима. У првом делу рада бавимо се студијама социјалне интеракције која прихвата социокултурну и дијалошку перспективу која тврди да социјалне интеракције не могу да се виде као једноставне варијабле које „имају утицаја“ на процес учења. У другом делу развијамо идеју да је аргументација културна активност са когнитивним и релационим, афективним и комуникативним особеностима. У трећем делу представљамо теоријске оквире педагошког пројекта који је имплементиран у универзитетски курс социјалне психологије.

После презентације методолошких средстава која смо користили за анализу наших података, сачињену од једанаест сесија у којима је учествовало тридесет пет студената, распоређених у групе 
по троје или четворо, дискутовали смо о резултатима анализе аргументоване дискусије коју су развили студенти. Да ли се они слажу или не слажу? Како подносе неслагање? Да ли их неслагање води у епистемолошко истраживање? Анализа се усредсређује пре свега на структуру сесија, а онда на аргументоване потезе, методолошким средством, као што је оно које су развили Нил Мерсер и колеге (истраживачки разговор) и Селма Леитао (Selma Leitao 2000). Резултати показују да студенти коконструишу социјални оквир у којем неслагање може да се изрази и „дубоко“ истраживање теме може да се развије. Овај налаз се анализира испитивањем улоге општег значаја као што је окружење у академском контексту.

Испитујући специфичан дизајн и објашњавајући теоријско порекло, надамо се да ћемо допринети одразу и комплексности процеса интеракције и конструкцији услова њене динамике. Важност развоја аргументованих вештина од стране студената, које се односе на одређено професионално поље, такође се наглашава.

Кључне речи: социокултурни приступ, учење, аргументација, неслагање, дизајн. 